\title{
Determination of Customer Satisfaction in Conservative Concept Hotels by Ordinal Logistic Regression Analysis
}

\author{
Hakan Eygu¹, Ali Caglar Gulluce ${ }^{2}$ \\ ${ }^{1}$ Faculty of Economics, Ataturk University, Erzurum, Turkey \\ ${ }^{2}$ Open Education Faculty, Ataturk University, Erzurum, Turkey \\ Email: hakaneygu@atauni.edu.tr, alichaglar@yahoo.com
}

How to cite this paper: Eygu, H., \& Gulluce, A. C. (2017). Determination of Customer Satisfaction in Conservative Concept Hotels by Ordinal Logistic Regression Analysis. Journal of Financial Risk Management, 6, 269-284.

https://doi.org/10.4236/jfrm.2017.63020

Received: July 26, 2017

Accepted: August 26, 2017

Published: August 29, 2017

Copyright (c) 2017 by authors and Scientific Research Publishing Inc. This work is licensed under the Creative Commons Attribution International License (CC BY 4.0).

http://creativecommons.org/licenses/by/4.0/

\begin{abstract}
The purpose of this study was to determine the satisfaction level and the expectations of the conservative hotel customers during their stay. For this purpose, a survey was conducted for customers who prefer to stay in conservative hotel facilities. Ordinal logistic regression analysis was conducted using a statistical package program on the data obtained with the help of questionnaires. 430 customers who were staying in conservative hotels were asked to answer 41 questions in the survey. As a result of the research, demographic characteristics of conservative hotel customers were found to be statistically significant between the dependent variable and their status of education levels, occupation status, monthly income, nationality, duration of hotel stay, previous hotel stay, and the desire to stay again in the same hotel. This is a unique study to determine as to whether the characteristics of conservative hotel customers in hotel facilities differ according to the individual and socio-cultural characteristics of customers, since the customer expectancy changes according to the period and conditions of the time of operation and to compare the current situation with the expectations of the customers.
\end{abstract}

\section{Keywords}

Halal Tourism, Conservative Hotel, Customer Satisfaction, Quality, Ordered Logistics Regression

\section{Introduction}

As a result of the rapid development of world tourism, the number of traveling customers and the development of tourism across the world are increasing every year. Hence, they have a direct influence on the choice of the hotel in terms of 
the hotel operations and the features that they offer. This has led to the emergence of very different types and styles of hotel businesses depending on the changes in the needs and desires of the customers based on the direction of these developments. On the other hand, these types of enterprises are developing Islamic hotel enterprises in line with the demand in the Islamic tourism market and thus as a result these types of hotels are gradually increasing their market share.

Islamic Tourism is a type of tourism in which the Islamic tourism operators serve according to the expectations of the customers and adhere to Islamic concepts and cultural experiences. When this service is provided, special care is taken to keep the quality at a very high level. This is because, if the expectations of the customers receiving the services cannot be fully met, it may not be possible to find a place on the market for a hotel providing such service. Whether the customer expectations are being met can be understood by analyzing customer complaints or by satisfaction studies that the business has conducted. In this direction, the business aims to increase the market share by increasing the quality of their service. In this case, as the service quality increases, it is inevitable that the hotel fees will also increase accordingly. If the development of this tourism can be evaluated by both domestic and foreign tourists, then it is understood that precautions are required to improve the quality of service. The target requires proper planning and marketing for each class of customers to benefit from this type of tourism. The target is important in terms of getting the opinions of the whole customer profile in terms of socio-economic angle and guiding the tourism in line with these opinions.

Shakiry (2006) stated that Islamic tourism is not only limited to religious tourism, but also includes all touristic activities that are not against Islamic values in tourism. Collins-Kreiner \& Wall (2015) point out that there is no relationship between religion and tourism and that there is little interaction between these issues. In addition, when tourism activities are being carried out, it has to be determined that which religious service will be offered and that the service providers should have the necessary knowledge about that particular religion.

Henderson (2010) defines Islamic tourism as a type of tourism in which all of the tourist products and services created for conservative people are designed totally for the purposes of conservative people.

El-Gohary (2016) examined the concept of halal tourism and examined whether halal tourism is indeed halal, and whether halal tourism is important only to those people belonging to Islam or to people of other countries as well.

The purpose of this study was to determine the factors that are relevant to customer satisfaction in conservative hotels, which are expected to have their incomes rise above 200 million dollars in the upcoming year. Hence, for this purpose, a survey has been conducted on the guests staying at conservative hotels and the data obtained as result of the study have been modelled using logistical regression method to process the results related to hotel satisfaction. In the 
first part of the study, the content and the results of previous literature have been examined and the second part of the study encompasses the work methodology along with the survey results; while the final part of the study contains general evaluation of study results.

\section{Literature Study}

\section{Satisfaction Expectation from Conservative Hotels}

Arpaci \& Batman (2015), gave the definition of a hotel with a halal concept, as the choice of the Muslims living their lives in accordance with the orders and prohibitions of Islamic religion, with separate areas such as pools for men and women, SPA, hammam (Turkish bath), restaurant, prohibited alcohol service, presence of prayer rugs, and preparing halal foods in the facility. Halal-concept hotels, besides the official classification that they have from the ministry, also certify that the certificates they receive from various associations and establishments are halal. Halal-concept hotels introduce themselves as halal, Islamic, conservative alternatives and they are marketed more costly as compared to classic hotels by highlighting these conservative features.

Barlow \& Moller (2009) stated in their research that an underestimation of complaints and dissatisfaction would lead to dissatisfaction of the customers and that the business would be adversely affected.

Craggs \& Schofield (2011) found that the most important feature of tourists' satisfaction in a facility is the cleanliness of the environment of the facility as the most important feature for that hotel.

In the study by Camaro \& Sabtu (2012), the Islamic hotels operating in Malaysia have been examined in terms of Halal Certificates. Criteria such as whether the food and drinks are prepared with Islamic sensitivity, whether the personnel are made up of Muslims, whether there are prayer rugs in the room, whether there are signs for the direction of Qabe have been examined, as these are important criteria for customer satisfaction in Islamic Hotels.

In the study by Met \& Özdemir (2012), the Islamic hotels operating in Turkey have been studied. The study has determined after review of 304 surveys conducted on hotel customers, that the factors which effect the customer decision include whether there is a separate pool for males and females; whether there is a separate Masjid for males and females; whether entry to the hotel is denied if there is no marriage certificate; whether there are sufficiently large enough rooms for activities; whether there are old style Turkish commodes and whether the clothes of employees are appropriate for such a place. Customer satisfaction will increase if the hotel gives service in concordance with the criteria above.

In the study by Kotler (2005); it was stated that in order to obtain customer satisfaction and customer loyalty; it was essential to develop clear hierarchy of company values, to conduct activities that create more better customer consciousness in the employees and in company representatives; and to simplify the process of handling complaints by taking questions and suggestions of the cus- 
tomers through phone, fax or mail and by providing fast replies to these queries.

Sriprasert et al. (2014) examined the behavioral expectations of Muslim tourists. The satisfaction enhancing factors for the holidays have been determined as signs showing the direction of Qabe, availability of halal food in the hotel, availability of a calendar showing prayer times and availability of prayer rugs in the rooms, suitability of hotel employees' clothing styles, and having separate pools for females and males.

In the study by Özdemir (2015), it was determined whether the characteristics of conservative hotel customers differed according to the personal and socio-cultural characteristics of the customers and also the expectations of the customers and the current situation were compared. For this purpose, a survey was conducted for customers who prefer to stay in conservative hotel businesses.

Qu \& Ping (1999), stated that the level of customer satisfaction depends on a significant amount on their travel and accommodation needs being met. Therefore, they stated that it is important to determine the level of satisfaction by taking the opinions of the customers.

In his study Mansouri (2014), it has been revealed whether there is a meaningful relationship between functioning, design and financial issues of the attributes of Islamic hotels and the attitudes of customers to Islamic hotels. As a result of the research, a significant relation was found between the functioning, design and financial issues related to the qualifications of the Islamic hotels and the attitudes of the customers towards Islamic hotels.

Aziz et al. (2015), studied the relationship between Islamic tourism and Halal tourism. They stated that the services such as travels, social activities, halal food and beverage services which are suitable for Islamic concepts are among the reasons of preference in this type of tourism selection.

$\mathrm{Lu}$ (1999) proposed a model using ordinal logit and regression analysis in his work on housing satisfaction. Since the satisfaction variables used in the analysis are in line with the ordinal logistic regression, it is suggested that using the ordinal logit model gives more reliable results. As a result, it is revealed that housing satisfaction is a structure affected by environmental and socio-demographic variables.

Rezai (2008) suggests that government incentives / grants for the production of halal foods affect the growth of this market in a survey of consumer confidence in food products in Malaysia. The logit model was used to determine the effectiveness of the survey questions according to the demographic characteristics of the participants. As a result of the binary logit model being used, the demographic characteristics of the participants have been determined as to their confidence in halal certified foods and their effect as to their awareness of these foods.

Lawson \& Montgomery (2006) investigated customer satisfaction using binary, nominal and ordinal analyzes of logistic regression analysis methods. This research has demonstrated the application of these three types of logistic regres- 
sion in many business areas and the evaluation process of customer satisfaction.

Şerbetçi \& Özçomak (2014) collected data by using questionnaires to determine the factors affecting the success of the students taking statistical and econometric courses by using ordinal logistic regression analysis. They have made suggestions as to how the success of the students can be increased.

Türkay (2015) analyzed the answers to each expression that are used to determine the quality of working life and loyalty workplace and the work sector as dependent variables, and their effects were analyzed using ordinal regression technique.

Ayhan (2006) investigated job motivation, job satisfaction and socio demographic characteristics of nurses' intention to quit their jobs in the Turkish Health Care System by ordinal logistic regression analysis.

Akın \& Şentürk (2012) examined the level of happiness according to socio-demographic characteristics through ordinal logistic regression analysis and compared the results with the results of other studies on this subject.

\section{The Significance of the Study}

The aim of this study is to determine the level of expectation and pleasure of the domestic \& foreign customers from the Islamic hotel enterprises that have significance among tourism enterprises.

This study is rather important as it investigates whether the expectations and satisfaction of hotel enterprises differ according to individual variables (gender, age, marital status, education status, monthly income) and socio-cultural variables (nationality) for domestic and foreign customers staying in Islamic hotels operating in Turkey.

It can be said that there are similar studies in the domestic and foreign literature as reference for the research. However, it can be said that this is a unique study to determine whether the characteristics of conservative hotel customers in hotel business are differentiated according to the individual and socio-cultural characteristics of customers as the customer expectancy changes according to time and circumstances and also to compare the expectations of customers with the current situation.

\section{Method}

Since the data used for the purpose of the study were categorical, the most appropriate statistical method was determined. It has been examined whether the obtained data meet the assumptions of the applied method. Ordinal logistic regression analysis was used within the study. Thanks to this analysis, the appropriate model was determined. The study has a model and the established model increase the originality and uniqueness of the study in terms of putting out and interpreting the results of the work.

Mc Cullagh (1980), is a model in which the observable dependent variable $\mathrm{Y}$ has $\mathrm{j}=0,1,2, \ldots, \mathrm{k}$ ordered scales. It is a method used to explain the relationship 
between variables when the dependent variable is categorical. This method is also categorized among consecutive categories, from low to high values. Ordinal Logistic Regression Method cannot be used when the ranking of categories is close (Menard, 2001). This method can be constructed as a ordinal category logistic regression model, a continuous rate model and a proportional odds model (Hosmer \& Lemeshow, 2000: 288). After modeling, the model needs to be statistically evaluated and tested (Çokluk, 2010: 1404). Statistics related to the test of the significance of the model, Chi-square statistic, $-2 \operatorname{LogL}$ statistic, Hosmer and Lemeshow G, Block Chi-square statistic are used.

Logit, complementary LogLog, Negative LogLog, Probit, Cauchit functions are used to configure Ordinal Logistic Regression model.

It was determined that it is appropriate to use Logistic Regression Method in the study, because the application subject was determined as satisfaction. This method can be examined in three different groups depending on the nature of the dependent variable: binary, ordinal, multinomial logistic regression.

The reason for using the logistic regression is that the function is highly mathematically flexible, easy to use, and can be interpreted meaningfully in terms of the results (Alpar, 2011: 624). Moreover, it is possible that the independent variables can be used without the need for important assumptions such as multivariate normal distribution and homogeneity of variance and covariance of known groups (Akın \& Şentürk, 2012: 184). The Ordinal Logistic Regression Method was used because of the order of satisfaction in the study and the dependency variable due to assumptions.

The characteristics of the ordinal logistic regression model are as follows (Chen \& Hughes, 2004: 4; Breslaw \& Mclntosh, 1998: 28).

- Dependent variable Y is an unobserved, latent variable (reorderable) ordered and grouped categorical variant. However, it is not certain whether the categorical of the ordinal variable are separated by equal intervals.

- Ordinal logistic regression analysis uses the link function to explain the effects on the explanatory ordinal categorical variable, without the normality and homogeneity assumption of variances.

- The ordinal logistic regression model assumes that the relationship between the explanatory variable and the ordered categorical variable is categorically independent, since the ordered categorical variable of the regression coefficient is not tied to the categorical.

In the ordinal logistic regression model let $\pi(x)=E(y \mid x)=P\{y=1 \mid x\}$ Where $x$, vector $\left\{x_{1}, x_{2}, \cdots, x_{k}\right\}$ of independent variables is expressed as; (O'Connell, 2006: 105; Frank \& Harrell, 2001: 568).

$$
\begin{aligned}
& \pi(x)=\frac{\exp \left(\beta_{0}+\beta_{1} x_{1}+\beta_{2} x_{2}+\cdots+\beta_{k} x_{k}\right)}{1+\exp \left(\beta_{0}+\beta_{1} x_{1}+\beta_{2} x_{2}+\ldots+\beta_{k} x_{k}\right)} \\
& =\frac{1}{1+\exp \left[-\left(\beta_{0}+\beta_{1} x_{1}+\beta_{2} x_{2}+\cdots+\beta_{k} x_{k}\right)\right]}
\end{aligned}
$$

$\pi(x)$ : The possibility of observing the phenomenon being examined, 
$\beta_{0}=$ When the arguments take a value of zero, the value of the dependent variable is fixed with another expression,

$\beta_{1}=$ The regression coefficients of the independent variables,

$x=$ Dependent variables.

The application of the ordinal logistic regression model depends on the provision of large dependent variables and model assumptions. In particular, the assumption of parallel curves, which is one of these hypotheses, must be achieved.

This assumption implies that the categories belonging to the dependent variable are parallel to each other. Hence, it is known as the parallel truth hypothesis and this tests the suitability of all the categories with the same parameter. When this assumption is not fulfilled; for example, if there are categories with few subjects, then they can be combined together and also when the assumption for $\mathrm{Bi}$ nary or Multinomial Logistic Regression Analysis is not met, then it can be used as an alternative (Sümbüloğlu \& Akdağ, 2007). Tests such as Wald Ki-Square test, likelihood ratio test, Brant Wald test are used to check the validity of the assumption of parallel curves. If the hypothesis of the parallel curves is zero and the alternative hypothesis is formed as:

$\mathrm{H}_{0}$ : Relevant regression coefficients are the same in all categories of dependent variable.

$\mathrm{H}_{1}$ : Relevant regression coefficients are different in all categories of dependent variable.

One of the statistical tests of the application of the model to be created is the statistic which shows whether the model represents the data well. The zero and alternative hypotheses testing the general validity of the model:

$\mathrm{H}_{0}$ : Model represents the data well.

$\mathrm{H}_{1}$ : Does not represent model data well.

In order for the model to be valid, the null hypothesis must be accepted (Kalayc1, 2010: 281).

Working research hypotheses are determined as:

H.1. There is a significant relationship between customer satisfaction and their gender.

H.2. There is a meaningful relationship between customer satisfaction and their age.

H.3. There is a meaningful difference between customer satisfaction and marital status.

H.4. There is a significant relationship between customer satisfaction and educational status.

H.5. There is a meaningful relationship between customer satisfaction and their profession.

\subsection{Sample}

In this study, the universe of the research is formed by the customers who are 
holidaying at conservative hotels in Turkey in 2016. The data set in the study was obtained by a questionnaire survey conducted by simple random sampling method. The data set to be used in the study consists of horizontal cross-section data obtained with the help of a questionnaire applied to conservative hotel operators. The determination of the sample size is based on the simple random sampling method,

$$
n=\frac{N P Q Z^{2}}{(N-1) d^{2}+P Q Z^{2}}
$$

Estimated formula was utilized for sample size (Eygü \& Yıldırım, 2016: 1642). In this formula:

$n=$ sample size

$N=$ Population density (number of customers in the Islamic Hotel Facilities)

$P=$ Percentage of Participants who want to stay in the hotel again

$Q=$ Percentage of Participants who don't want to stay in the hotel again (1-P).

$Z=\%(1-\alpha)$ is the $Z$ Test value

$\alpha=$ Significance Level

$d=$ Error (Tolerance) share

Participants who did not want to stay in the hotel again were taken as a ratio of 0.5 to be as large a sample as possible and they were calculated as the sample size to represent the population at 5\% significance level and $0.5 \%$ error rate,

$$
n=\frac{N P Q Z^{2}}{(N-1) d^{2}+P Q Z^{2}}=\frac{1486(0.5)(0.5)(1.96)^{2}}{(1486-1) 0.05^{2}+(0.5)(0.5)(1.96)^{2}} \cong 305
$$

The minimum sample size targeted in the study was 305. A total of 430 surveys were carried out, considering that there may be missing and incorrectly filled surveys. Cronbach's alpha coefficient was found to be 0.695 for the 41 questions in the remaining 407 questionnaires after missing and incorrectly filled questionnaires were removed from the study. This result shows that the survey can be used with approximately $70 \%$ confidence. Stratified random sampling method was preferred in order to obtain closer estimates to the mean of the population by better representing the population in the sample in parallel with the number of customers in the hotels.

The division of the units in terms of characteristics, qualities or qualities which are similar to each other is called the layer. The process of estimating the population parameters by selecting simple random samples from each layer by dividing the population into subgroups, which are not intersecting with each other, is called layered random sampling. Units are selected independently from each layer (Özdemir, Tekin, \& Esin, 2015: 167-168).

\subsection{Data Collection Tool}

Research scales for satisfaction of service quality in Islamic-concept hotel enterprises which are to be used for collection of research data consist of expressions about whether or not domestic and foreign customers belonging to Islamic reli- 
gions who are staying in Islamic hotels are satisfied with the services provided by hotel enterprises. The questionnaire to be used as a data collection tool contains understandable statements by all the individuals in the sample. It is assumed that the results found at the end of the study encompass the research universe.

In this study, Likert scale with 5 dependent variables (1: strongly disagree, 2 : disagree, 3: undecided, 4: agree, 5: strongly agree) were used. A ranking of the small size (by participation level) was also obtained, which is also appropriate for the proposal for ordinal regression measures. In ordinal regression analysis, the dependent variable must be measured at ordinal level. Two separate dependent variables tested in the study were measured using the Likert type scale. Some researchers describe the Likert-type scale as an ordered scale (Hox, 2010: 141). In this study, the data obtained from the questionnaire using Stata 13.0 computer package program were analyzed with the help of logistic regression analysis and ordinal logistic regression model. Ordinal regression analysis is a method used when the categories of the dependent variable are measured on a ordinal scale. Model-selected variables are used in cases where the dependent variable has more than two categories and sequenced.

\section{Findings and Discussions}

By using logistic regression analysis and ordinal logit model, the determination of what factors are influential in the satisfaction of Islamic concept hotel customers and the magnitude of their effects have been examined. All demographic variables were included as independent variables in the model, because it was assumed that the demographic variables of the questionnaire could directly or indirectly influence the satisfaction of the customers. Descriptive statistical results for these variables are given in Table 1.

The model with maximum likelihood in which the independent variables given in Table 1 that influence hotel satisfaction can be obtained is the logit model. The analysis results of the predicted model are summarized in the following Table 2 customers out of 407 customers who participated in the survey were found to be not satisfied with the hotel, 28 were undecided and 377 customers were found to be satisfied.

The next step is to model the satisfaction levels of the hotel according to socio-demographic characteristics. The modeling is conducted with the aid of the logit link function. Previously, it was stated that there are some assumptions for using ordered logit model. Here, the assumption of parallelism must first be achieved. Therefore, the suitability of this assumption should be initially tested.

The parameters for parallelism hypothesis were specified for the statistical values to pass over a line for all categories of the dependent variable. One of the most important assumptions in the ordinal logistic regression model is the assumption of parallel curves. According to this assumption, it can be defined as a method that tests the variables under the assumption that the determined regression coefficients are equal in all the categories of the ordered categorical 
Table 1. Descriptive Statistics for Independent Variables Used in the Logit Model.

\begin{tabular}{|c|c|c|c|c|c|}
\hline Variables & Frequency(N) & Percentage (\%) & Variables & Frequency (N) & Percentage (\%) \\
\hline Gender & & & Monthly Income & & \\
\hline Female & 186 & 45.7 & $1000 \mathrm{TL}$ and below & 67 & 16.5 \\
\hline Male & 221 & 54.3 & $1001-2000 \mathrm{TL}$ & 20 & 4.9 \\
\hline Age & & & $2001-3000 \mathrm{TL}$ & 50 & 12.3 \\
\hline $18-25$ & 120 & 29.5 & $3001-4000 \mathrm{TL}$ & 128 & 31.4 \\
\hline $26-33$ & 23 & 5.7 & $4001 \mathrm{TL}$ and above & 103 & 25.3 \\
\hline $34-41$ & 99 & 24.3 & Nationality & & \\
\hline $42-49$ & 100 & 24.6 & T.C & 268 & 65.8 \\
\hline 50 and above & 65 & 16 & Other & 139 & 34.2 \\
\hline Marital Status & & & Hotel Stars & & \\
\hline Married & 316 & 77.6 & 3 stars & 146 & 35.9 \\
\hline Single & 91 & 22.4 & 4 stars & 97 & 23.8 \\
\hline Education Status & & & 5 stars & 137 & 33.7 \\
\hline Elementary School & 7 & 1.7 & Other & 27 & 6.6 \\
\hline High School & 74 & 18.2 & Duration of stay in the hotel & & \\
\hline Undergraduate & 294 & 72.2 & $1-4$ days & 194 & 47.7 \\
\hline Graduate Level & 16 & 3.9 & 5 - 8 days & 85 & 20.9 \\
\hline Doctorate & 16 & 3.9 & 9 and above & 128 & 31.4 \\
\hline Occupation & & & Did you stay in a conservative hotel before? & & \\
\hline Clerk & 146 & 35.9 & Yes & 264 & 64.9 \\
\hline Laborer & 23 & 5.7 & No & 143 & 35.1 \\
\hline Tradesman & 91 & 22.4 & Would you like to stay again in the same hote? & & \\
\hline Retired & 6 & 1.5 & Yes & 377 & 92.6 \\
\hline Student & 87 & 21.4 & No & 30 & 7.4 \\
\hline Housewife & 35 & 8.6 & & & \\
\hline Others & 19 & 4.7 & & & \\
\hline
\end{tabular}

Table 2. Parallelism Hypothesis Testing.

\begin{tabular}{ccccc}
\hline Model & -2 Log Likelihood & $\chi^{2}$ & sd & $p$ \\
\hline $\mathrm{H}_{0}$ hypothesis & 348.380 & & & \\
General & 316.024 & 22.04 & 44 & 0.059 \\
\hline
\end{tabular}

$\mathrm{H}_{0}=$ Averages for distributions go through the same line. $\mathrm{H}_{1}=$ Averages for distributions are passed through the heading.

variable. That is, the relationship between independent variables and dependent variables does not change according to the categories of the dependent variable.

This hypothesis was tested by Chi-square test, the assumption of parallelism $(p>0.05)$ was provided as statistically significant and the null hypothesis was 
accepted. In other words, if the significance of this test is greater than 0.05 , it means that for the parameter estimation values, the dependent variable passes over all the categories on the same line. This means that $\mathrm{H}_{0}$ hypothesis is accepted and $\mathrm{H}_{1}$ hypothesis is rejected.

The fit-goodness test of the model is given in Table 3 using Pearson Chi-square and deviation statistics.

As shown in Table 3, the model's suitability is determined using the difference between the observed and expected values of the model. Therefore, it was assumed that the model was in agreement with the assumption that $p>0.05$ as statistically significant and that the null hypothesis was accepted.

In Table 4 , the $\mathrm{R}^{2}$ values of the model are calculated, showing how many percent of the dependent variable is explained by the independent variables. However, these values do not give definite results.

In this model, there are 11 independent variables (gender, age, marital status, educational status, occupation, monthly income, nationality, hotel class, effective factor in hotel choice, previous accommodation in conservative hotels) are found and the probability of these variables are examined. These probability values are the values of the Wald test to determine whether the parameters are meaningful. When the analysis results are examined in Table 5, the significance level was found to be statistically significant when $\mathrm{p}$ values of some variables were less than 0.05 . The reference category in the study was made according to the interpretations determined as the last category.

According to the ordinal logistic regression analysis in Table 5, the reference category was determined as the last category for each independent variable, and the interpretations were made accordingly. Two categories of the threshold values calculated in the model are significant. In addition, when the independent variables explaining the expressions of satisfaction from the hotel are examined, it was found that a meaningful relationship exists for two categories in the case of education, two categories of occupational status, one category of monthly income, one being a citizen of a national or a foreign country, two categories in the duration of the hotel stay, and for one category for a repeated stay at the same hotel. When the value of each of these significant variables increases by 1 unit, it

Table 3. Compliance Goodness Test.

\begin{tabular}{cccc}
\hline Model & $\chi^{2}$ & Sd & $\boldsymbol{p}$ \\
\hline Pearson & 622.310 & 435 & 0.071 \\
Deviation & 445.969 & 435 & 1.000 \\
\hline
\end{tabular}

$\mathrm{H}_{0}=$ Model data is suitable; $\mathrm{H}_{1}=$ Model data is not suitable.

Table 4. Pseudo $\mathrm{R}^{2}$ Values.

\begin{tabular}{cc}
\hline Cox and Snell & 0.066 \\
Nagelkerke & 0.089 \\
McFadden & 0.093
\end{tabular}


Table 5. Parameter Estimates.

\begin{tabular}{|c|c|c|c|c|c|c|c|}
\hline & & $\begin{array}{c}\text { B } \\
\text { Coefficients }\end{array}$ & s.h & Wald & s.d & $p$ & $\begin{array}{c}\text { Exponential } \\
\text { B Values }\end{array}$ \\
\hline \multicolumn{8}{|c|}{ Dependent Variable } \\
\hline \multirow{14}{*}{ 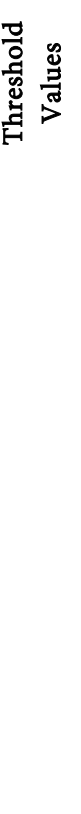 } & [satisfaction $=2$ ] & 0.017 & 0.126 & 0.019 & 1 & 0.891 & 1.017 \\
\hline & {$[$ satisfaction $=3$ ] } & 3.124 & 1.002 & 9.417 & 1 & $0.002^{*}$ & 22.737 \\
\hline & {$[$ satisfaction $=4]$} & 8.391 & 1.035 & 65.112 & 1 & $0.000^{\star}$ & 4407.223 \\
\hline & {$[$ Gender $=1]$} & -0.679 & 0.351 & 3.744 & 1 & 0.053 & 0.507 \\
\hline & [age $=1]$ & 1.022 & 0.770 & 1.763 & 1 & 0.184 & 2.779 \\
\hline & [age $=2]$ & 0.424 & 0.811 & 0.273 & 1 & 0.601 & 1.528 \\
\hline & {$[$ age $=3]$} & -0.226 & 0.558 & 0.164 & 1 & 0.686 & 0.798 \\
\hline & {$[$ age $=4]$} & -0.605 & 0.527 & 1.317 & 1 & 0.251 & 0.546 \\
\hline & {$[$ Marital status $=1]$} & 2.007 & 1.596 & 1.581 & 1 & 0.209 & 7.441 \\
\hline & {$[$ Education Status $=1]$} & -1.109 & 0.922 & 1.446 & 1 & 0.229 & 0.330 \\
\hline & [Education Status $=2$ ] & -2.765 & 0.847 & 10.648 & 1 & $0.001^{*}$ & 0.063 \\
\hline & [Education Status $=3$ ] & -2.044 & 1.031 & 3.929 & 1 & $0.047^{*}$ & 0.130 \\
\hline & [occupation $=1$ ] & 10.648 & 1.067 & 2.386 & 1 & 0.122 & 5.197 \\
\hline & [occupation $=2$ ] & 0.795 & 1.097 & 0.525 & 1 & 0.469 & 2.214 \\
\hline \multirow{16}{*}{ 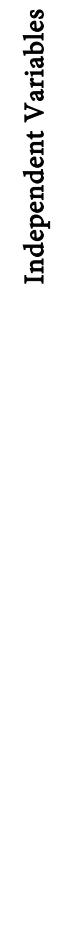 } & [occupation $=3$ ] & 3.616 & 1.052 & 11.804 & 1 & $0.001^{\star}$ & 37.189 \\
\hline & [occupation $=4]$ & 0.814 & 0.983 & 0.686 & 1 & 0.408 & 2.257 \\
\hline & [occupation $=5$ ] & 3.763 & 1.548 & 5.912 & 1 & $0.015^{*}$ & 43.078 \\
\hline & [occupation $=6$ ] & 1.658 & 1.366 & 0.1472 & 1 & 0.225 & 5.249 \\
\hline & [monthly income $=1]$ & 0.671 & 0.656 & 1.046 & 1 & 0.306 & 1.956 \\
\hline & [monthly income $=2$ ] & 0.833 & 0.936 & 0.793 & 1 & 0.373 & 2.300 \\
\hline & [monthly income $=3$ ] & 0.345 & 1.025 & 0.113 & 1 & 0.737 & 1.142 \\
\hline & [monthly income $=4$ ] & 1.015 & 0.446 & 5.182 & 1 & $0.042^{*}$ & 2.759 \\
\hline & [nationality = 1] & -0.611 & 0.307 & 3.930 & 1 & $0.047^{\star}$ & 0.543 \\
\hline & [hotel type = 1] & 1.233 & 1.546 & 0.686 & 1 & 0.425 & 3.432 \\
\hline & [hotel type $=2$ ] & -0.935 & 1.556 & 0.361 & 1 & 0.548 & 0.393 \\
\hline & [hotel type $=3$ ] & -2.054 & 1.570 & 1.713 & 1 & 0.191 & 0.128 \\
\hline & [duration of stay in the hotel =1] & -2.980 & 0.917 & 10.568 & 1 & $0.001^{*}$ & 0.051 \\
\hline & [duration of stay in the hotel $=2$ ] & -3.051 & 0.912 & 11.182 & 1 & $0.001^{*}$ & 0.047 \\
\hline & [Status of staying in a similar hotel $=1$ ] & 0.915 & 0.394 & 5.403 & 1 & $0.020^{*}$ & 2.497 \\
\hline & [would you like to stay again in the same hotel $=1$ ] & -1.932 & 0.579 & 11.121 & 1 & $0.001^{*}$ & 0.145 \\
\hline
\end{tabular}

${ }^{\star} p<0.05$ shows significance level.

is observed that the predicted rate of the dependent variable will also increase.

When the educational status is examined in Table 5, the reference category is the category designated as a graduate level, since this variable is the same num- 
ber that responds to the post-graduate and doctoral choices. In this case, the customers with high school and university education levels were found to be statistically significant $(p<0.05)$ as compared to the graduate degree holder customers. In other words, it can be said that the educated high school graduates are 0.06 times more satisfied than the graduate degree level customers and the undergraduate degree holder customers are 0.13 times more satisfied than the graduate degree holder customers.

When the occupational status is examined, it is seen that that tradesman are 37 times more satisfied as compared to other occupations in the study. It is also seen that retired customers are 43 times more satisfied than people working for other professional organizations.

When the study results are analyzed for monthly income, it is seen that the customers with income level between $3001-4000 \mathrm{TL}$ are 2.8 times more satisfied than the customers with income level higher than $4001 \mathrm{TL}$. When we examine the variable of whether the customers are domestic or foreign nationals, it is seen that the customers who are Turkish citizens are approximately 0.54 times more satisfied than the customers who are foreign citizens. When the variable of the average number of days spent at the hotel is analyzed, it is seen that the customers who spend 1 - 4 days in the hotel are satisfied with the hotel about 0.05 times more than the customers who spend 9 days or more at the hotel. In addition, it can be said that the customers who stay in the hotel between 5 - 8 days are also 0.04 times more satisfied than the customers who stayed over 9 days. It is observed that the customers who were staying at the hotel for a repeated time were approximately 2.50 times more satisfied than the ones staying for the first time. The question of "whether you want to stay in this hotel again," was found to be statistically $(p<0.05)$ meaningful.

\section{Conclusion}

Nowadays, hotel operators try to meet the expectations of customers by investigating to find out the expectations of their customers. Because the businesses that serve in this manner realize that they can only exist with the existence of their customers. In this direction, hotel operators are aware that the reason for preference will increase if the customer is successful in showing more interest and providing quality service. In this study, it has been seen that customer satisfaction is very important in terms of hotel management. Likewise Hui, Wan, \& Ho (2007) stated that customers who are not satisfied with the products and services offered by the hotels will not choose to return to the same hotel again and will also share the negative feedback with their social circles. Özdemir (2015) stated that $90 \%$ of the customers who are not satisfied with their hotel do not buy services from the same hotel again and share their dissatisfaction with at least 10 other people. In addition, it is observed that the current situation for conservative hotels is examined and that the tourists who stay at these hotels are not satisfied with their expectations of services. Examining similar works in the 
Islamic tourism sector by industry or sector managers, it can be stated that it would be of benefit to the operators of their activities to eliminate their deficiencies by making their own assessments based on the resultant expectation scale.

At the end of the study, it is seen that the customers who stay in conservative hotels are satisfied with the current service provided as per the expectations of the customers. The customers who have participated in the study have stated that $0.5 \%$ is not satisfied, $6.9 \%$ is undecided, and $92.6 \%$ have stated that they were satisfied with the services. In the ordinal logistic regression model for the satisfaction of Islamic hotel customers, independent variables such as educational status, occupation, monthly income, nationality of the country, the period of staying in the hotel, staying in conservative hotel previously and wanting to stay in the hotel are statistically significant variables.

It is seen that the customers staying in Islamic hotel companies generally respond to hotel expectations. However, the services offered in Islamic tourism needs to be constantly renewed according to the expectations and needs of the customers. That is why businesses can increase their preference and their effectiveness in this market by offering new possibilities to their customers. According to the information given in the study, information can be obtained according to the demands of the customers and opportunities can be offered to make them more satisfied. It should not be forgotten that customer satisfaction is a very important factor in service providers. Therefore, in general, businesses are required to pay attention to activities that will meet customer expectations, and to ensure that all employees in the business are involved in meeting customer expectations.

\section{References}

Akın, B. H., \& Şentürk, E. (2012). Determination of the Happiness Levels of Individuals by Ordinal Logistic Regression Analysis. Oneri Journal, 10, 183-193.

Alpar, R. (2011). Applied Multivariate Statistical Methods (3rd ed.). Ankara: Detay Press.

Arpac1, Ö., \& Batman, O. (2015). The Effect of Perceived Service Quality of Halal Concept Hotel Companies on Customer loyalty and Customer Value in High \& Low Session. Journal of Travel and Hotel Management, 12, 73-86.

Ayhan, S. (2006). Determination of Affecting Factors for Nurses' Intention to Leave Jobs in Turkey by Ordinal Logistic Regression Analysis. Unpublished Master Thesis, Eskişehir: Department of Statistics, Institute of Science, Osmangazi University.

Aziz, Y. A., Rahman, A. A., Hassan, H., \& Hamid, S. H. (2015). Exploring the Islamic and Halal Tourism Definition. Hospitality and Tourism, Proceedings of HTC 2015, Malacca, Malaysia, 2-3 November 2015, 139. https://doi.org/10.1201/b19162-31

Barlow, J., \& Moller, C. (2009). Rocovering Customer Loyalty When Things Go Wrong A Complaint is a Gift (2nd ed., pp. 17-19). Oakland, CA: Berrett-Koehler Publishers.

Battour, M., Ismail, N. M., Battor, M., \& Awais, M. (2017). Islamic Tourism: An Empirical Examination of Travel Motivation and Satisfaction in Malaysia. Current Issues in Tourism, 20, 50-51. https://doi.org/10.1080/13683500.2014.965665

Breslaw, J. A., \& Mclntosh, J. (1998). Simulated Latent Variable Estimation of Models with Ordered Categorical Data. Journal of Econometrics, 87, 25-47. 
https://doi.org/10.1016/S0304-4076(98)00004-9

Camaro, Z., \& Sabtu, S. (2012). Developing Halal Standart for Malaysian Hotel Industry: An Exploratory Study. International Halal Conference, PWTC, Kuala Lumpur, Malaysia.

Chen, C. K., \& Hughes, J. (2004). Using Ordinal Regression Model to Analyze Student Satisfaction Questionnaires. Association for Institutional Research, 1, 1-13.

Collins-Kreiner, N., \& Wall, G. (2015). Tourism and Religion: Spiritual Journeys and Their Consequences, The Changing World Religion Map (pp. 689-707). Netherlands: Springer.

Craggs, R., \& Schofield, P. (2011). The Quays in Salford: An Analysis of Visitor Perceptions, Satisfaction and Behavioural Intention. International Journal of Tourism Research, 13, 583-599. https://doi.org/10.1002/jtr.831

Çokluk, Ö. (2010). Logistic Regression: Concept and Application. http://files.eric.ed.gov/fulltext/EJ919857.pdf

El-Gohary, H. (2016). Halal Tourism, İs İt Really Halal? Tourism Management Perspectives, 19, 124-130.

Eygü, H., \& Yıldırım, O. (2016). Factors Affecting the Selection of Establishment and Facility Location by Regression Analysis: A Study on Eastern Anatolia. Ataturk University Journal of Social Sciences Institute, 20, 1635-1648.

Frank, E., \& Harrell, J. (2001). Regression Modeling Strategies, with Applications to Linear Models, Logistic Regression and Survival Analysis (p. 568). Springer Series in Statistics.

Henderson, J. C. (2010). Sharia-Compliant Hotels. Tourism and Hospitality Research, 10, 246-254. https://doi.org/10.1057/thr.2010.3

Hox, J. J. (2010). Multilevel Analysis, Techniques aand Applications (2nd ed.). Abingdon-on-Thames: Routledge.

Hosmer, D. W., \& Lemeshow, S. (2000). Applied Logistic Regression (2nd ed.). New York, NY: A Wiley-Interscience Publication. https://doi.org/10.1002/0471722146

Hui, T. K., Wan, D., \& Ho, A. (2007). Tourists' Satisfaction, Recommendation and Revisiting Singapore. Tourism Management, 28, 965-975.

Kalaycı, Ş. (2010). SPSS Applied Multivariate Statistical Techniques (5th ed.). Ankara: Asil Publication.

Kotler, P. (2005). Ten Deadly Marketing Sin. Translated by: Banu Adiyaman, Istanbul: Kapital Medya.

Lawson, C., \& Montgomery, C. D. (2006). Logistic Regression Analysis of Customer Satisfaction Data. Quality and Reliability Engineering International, 22, 971-984. https://doi.org/10.1002/qre.775

Lu, M. (1999). Determinants of Residential Satisfaction: Ordered Logit vs. Regression Models. Growth and Change, 30, 264-287. https://doi.org/10.1111/0017-4815.00113

Mansouri, S. (2014). Role of Halal Tourism Ideology in Destination Competitiveness: A Study on Selected Hotels in Bangkok, Thailand. In International Conference on Law, Education and Humanities, Pattaya, Thailand.

Mc Cullagh, P. (1980). Regression Models for Ordinal Data. Journal of the Royal Statistical Society, 42, 109-142.

Met, Ö., \& Özdemir, İ. M. (2012). The Expectations of Muslim Religious Customers in the Lodginin Industry: The Case of Turkey. In Zanial et al. (Eds.), Proceedings of the 
International Hospitality and Tourism Conference (p. 323). London: Taylor and Francis Group.

Menard, S. (2001). Applied Logistic Regression Analysis (2nd ed.). London: Sage Publications.

O’Connell, A. A. (2006). Logistic Regression Models for Ordinal Response Variables (No. 146). Thousand Oaks, CA: Sage Publications.

Özdemir, H. (2015). A Study for Determining the Characteristics of Conservative Hotel Customers in Hotels. PhD Dissertation, Ankara: Gazi University Institute of Education Sciences.

Özdemir, A. Y., Tekin, Ş. T., \& Esin, A. A. (2015). Introduction to Sampling Methods with Solved Samples. Ankara: Seçkin Publishing.

Qu, H., \& Ping, E. W. Y. (1999). A Service Performance Model of Hong Kong Cruise Travelers' Motivation Factors and Satisfaction. Tourism Management, 20, 237-244.

Rezai, G. (2008). Consumers' Confidence in Halal Labeled Manufactured Food in Malaysia. Published Doctor of Philosophy Universitiy Putra Malaysia.

http://psasir.upm.edu.my/4736/

Şerbetçi, A., \& Özçomak, S. M. (2014). Determining Factors Affecting Success in Statistical and Econometrics Lessons with Ordinal Logistic Regression Analysis: A Study on the students of Ataturk University Faculty of Economics. Journal of Kahraman Maras Sutcu Imam University Journal of Faculty of Economics, 3, 89-110.

Shakiry, A. S. (2006). Religious Tourism: The Pivot of Tourism between Islamic Countries and Attraction of Muslim World (İssue 34).

http://www.islamictourism.com/Articles/articles.php?issue $=34$

Sriprasert, P., Chainin, O., \& Abd Rahman, H. (2014). Understanding Behavior and Needs of Halal Tourism in Andaman Gulf of Thailand: A Case of Asian Muslim. Journal of Advanced Management Science, 2, 216-219.

https://doi.org/10.12720/joams.2.3.216-219

Sümbüloğlu, K., \& Akdağ, B. (2007). Regression Methods and Correlation Analysis. Ankara: Hatipoğlu Publication.

Türkay, O. (2015). The Effects of Work Life Quality on Job Satisfaction and Commitment: A Research on Travel Agencies. Management and Economy Journal, 22, 239-256. http://www.islamictourism.com/Articles/articles.php?=issue34 
Submit or recommend next manuscript to SCIRP and we will provide best service for you:

Accepting pre-submission inquiries through Email, Facebook, LinkedIn, Twitter, etc. A wide selection of journals (inclusive of 9 subjects, more than 200 journals)

Providing 24-hour high-quality service

User-friendly online submission system

Fair and swift peer-review system

Efficient typesetting and proofreading procedure

Display of the result of downloads and visits, as well as the number of cited articles Maximum dissemination of your research work

Submit your manuscript at: http://papersubmission.scirp.org/

Or contact jfrm@scirp.org 